Take a good look at the 1968 Iowa Road Map in the glove compartment of your car. As you see, it isn't far to Des Moines. Interstates 35 and 80 will deliver you in a hurry.

Make it the camper this time. After the children have visited the Conestoga and you have scanned Horn's Overland Guide, you may want to drive on to the Missouri slope to see if you can discover the site of the Council Bluffs Agency Ferry.

Make it sleeping bags, too. You will want to bed down under the stars. In another decade your young people may be traveling by radar and rocket to the moon and Mars. This year give them time to become acquainted with the Missouri, the sounds of the night, the stories of men and women of courage who dared the West.

\title{
1906 VOTING MACHINE ADDED TO HISTORICAL MUSEUM
}

One of the first voting machines used in this state is now on display on the third floor of the State Historical Museum, Des Moines. This machine was purchased from the Automatic Voting Machine Division, Jamestown, New York, by Johnson County in 1906. It was donated to the Department of History and Archives in June, 1968, by the Automatic Voting Machine Division, Jamestown, New York, Mr. L. A. Dixon, Jr., President.

According to the book Effects of the Use of Voting Machines on Total Votes Cast: Iowa - 1920-1960, George B. Mather, University of Iowa, 1964, the original act permitting the use of voting machines was adopted in 1900; by 1920 , 18 Iowa counties were equipped with voting machines. By 1922 , there were 20 Iowa counties using voting machines and by 1960, 37 counties used voting machines in the general election. 
Copyright of Annals of Iowa is the property of State of Iowa, by \& through the State Historical Society of Iowa and its content may not be copied or emailed to multiple sites or posted to a listserv without the copyright holder's express written permission. However, users may print, download, or email articles for individual use. 